\title{
A microbiological method for assessing the nutritional value of proteins
}

\author{
BY J. E. FORD \\ National Institute for Research in Dairying, Shinfield, Reading
}

(Received 18 March 1960-Revised 12 fuly 1960)

The accepted methods for measuring the nutritional value of proteins involve the use of common laboratory animals-mice, rats, chicks, dogs and others. They are laborious and costly, and much too slow for routine use for evaluating large numbers of protein samples, as in the control of the quality of animal feeding-stuffs. Several microbiological methods-some with bacteria and some with the protozoan Tetrahymena pyriformis as test organism-have been recommended for this purpose (for a review see Rosen, 1960), but none has yet been widely accepted, despite apparent advantages in simplicity and convenience. Of the bacteria, strains of Streptococcus faecalis and Leuconostoc mesenteroides have been investigated. Neither species has the ability to utilize intact protein, and hydrolysis of the test samples is a necessary preliminary to the assays. Chemical hydrolysis is not satisfactory, particularly when the purpose of the test is to evaluate foodstuffs that have been heated during processing. Such heating may cause destruction of amino acids in the food protein and 'binding' of amino acids so that they are not liberated by digestion in vivo or by enzymic hydrolysis in vitro but are released by acid hydrolysis (Evans \& Butts, I948). These problems, and the further complications that arise from the destructive effects of chemical hydrolysis on certain amino acids, have been avoided by the use of proteolytic enzymes. For assays with $S$. faecalis, Halevy \& Grossowicz (I953) hydrolysed a variety of proteins for $48 \mathrm{~h}$ with pancreatin and determined the quantities of the hydrolysates needed to promote half-maximum growth in their test cultures. Only about $40 \%$ of the proteins was hydrolysed during the enzymic digestion, but the results of the tests were broadly similar to those of rat-growth tests.

Horn, Blum, Womack \& Gersdorff (1952) and Horn, Blum \& Womack (I954) used $L$. mesenteroides $\mathrm{P}-60$ to grade a number of differently processed cottonseed meals. The meals were incubated for successive $24 \mathrm{~h}$ periods with pepsin, trypsin and a preparation of pig-gut mucosa. The growth of the test organism with these enzymic digests was compared with that obtained with a digest of a reference 'standard' meal, and 'indices of protein value' were computed which agreed fairly well with the findings in rat-growth tests. The value of the method for grading other types of protein was not investigated.

Tests of protein quality with the protozoan Tetrahymena pyriformis simulate more closely the circumstances of the biological test. Tetrahymena has much the same pattern of requirement for amino acids as the growing rat and is able to utilize intact proteins. Rosen \& Fernell (1956) have refined the technique of assay and have demon- 
strated its value for predicting the nutritional quality of protein foodstuffs for higher animals. Their procedure is unfamiliar and complex compared with conventional methods of microbiological assay, and seems better suited to the requirements of the research worker in nutrition than of the analyst. An object of this paper is to describe a quicker and simpler method, in which a strain of Streptococcus zymogenes is used as the test organism. S. zymogenes requires much the same pattern of exogenous amino acids as Tetrahymena: it is powerfully proteolytic, and grows quickly with an adequate intact protein as the main source of nitrogen. Ratings obtained for a variety of food proteins by the method of assay to be described agree reasonably well with values obtained in biological tests with rats, and the amino acids limiting growth can be simply identified.

\section{EXPERIMENTAL}

\section{Test organism}

The culture of $S$. zymogenes was obtained from the National Collection of Dairy Organisms at the National Institute for Research in Dairying, Shinfield, Reading. It is identified as culture no. NCDO 592.

Culture medium. The basal medium (Table 1 ) was developed empirically by modifying the medium of Ford, Perry \& Briggs (1958). The amino acids were omitted, and the $\mathrm{pH}$-buffering characteristic was modified in order to minimize the fall in $\mathrm{pH}$ that occurs during the growth of the test cultures.

Table 1. Composition of basal medium (five times single strength)

$\begin{array}{lc}\text { Glucose }(\mathrm{g}) & 12 \\ \mathrm{~K}_{2} \mathrm{HPO}_{4}(\mathrm{~g}) & 12 \\ \text { Citric acid }(\mathrm{g}) & 0.5 \\ \text { Sodium acetate (trihydrate) }(\mathrm{g}) & 2 \cdot 5 \\ \text { Tween 80* (ml) } & \mathrm{I} \\ \text { Solution of mineral salts } \dagger(\mathrm{ml}) & 10 \\ \text { Adenine (mg) } & 5 \\ \text { Guanine (mg) } & 5 \\ \text { Uracil (mg) } & 5 \\ \text { Xanthine (mg) } & 5\end{array}$

$\begin{array}{lc}\text { Thiamine (mg) } & 2 \\ \text { Pyridoxal (pyridoxal ethylacetal } & 2 \\ \text { hydrochloride) (mg) } & \\ \text { Riboflavin (mg) } & 2 \\ \text { Nicotinic acid (mg) } & 2 \\ \text { Calcium pantothenate (mg) } & 2 \\ \text { Folic acid (mg) } & 0.2 \\ \text { p-Aminobenzoic acid (mg) } & 2 \\ \text { Biotin }(\mu \mathrm{g}) & 10 \\ \text { Vitamin } \mathrm{B}_{12}(\mu \mathrm{g}) & 2 \\ \text { Ascorbic acid }(\mathrm{g}) & 0.5\end{array}$

$\mathrm{pH}$ adjusted with $\mathrm{N}$-acetic acid to $7 \cdot 2$.

Water added to $200 \mathrm{ml}$.

* Polyoxyethylenesorbitan mono-oleate.

† Contains $\mathrm{MgCl}_{2} .6 \mathrm{H}_{2} \mathrm{O}, 20 \mathrm{~g} ; \mathrm{CaCl}_{2}, 5 \mathrm{~g} ; \mathrm{FeCl}_{3} .6 \mathrm{H}_{2} \mathrm{O}, 0.5 \mathrm{~g} ; \mathrm{ZnSO}_{4} \cdot 7 \mathrm{H}_{2} \mathrm{O}, 0.5 \mathrm{~g} ; \mathrm{MnSO}_{4} \cdot 4 \mathrm{H}_{2} \mathrm{O}$, $0.25 \mathrm{~g} ; \mathrm{CoCl}_{2} .6 \mathrm{H}_{2} \mathrm{O}, 0.25 \mathrm{~g} ; \mathrm{CuSO}_{4} .5 \mathrm{H}_{2} \mathrm{O}, 0.25 \mathrm{~g} ; \mathrm{VSO}_{4}, 0.25 \mathrm{~g} ; \mathrm{Na}_{2} \mathrm{MoO}_{4}, 0.25 \mathrm{~g}$, dissolved in 11 . distilled water with addition of $\mathrm{N}^{-\mathrm{H}_{2}} \mathrm{SO}_{4}$ to clear.

Maintenance of stock cultures. The stock cultures were grown at $37^{\circ}$ for $24 \mathrm{~h}$, first in a broth comprised of basal medium supplemented with $200 \mathrm{mg}$ Tryptone (Oxo Ltd)/100 $\mathrm{ml}$, and then in stab culture in basal medium supplemented with $150 \mathrm{mg}$ casein, $15 \mathrm{mg}$ sodium glutamate and $1.5 \mathrm{~g}$ agar/ $100 \mathrm{ml}$. The stab cultures were stored at $2^{\circ}$ and subcultured at intervals of $I$ month.

Preparation of inocula for protein assays. Assay tubes were inoculated each with I drop of a 24 h culture (undiluted) grown in basal medium supplemented with $\mathrm{I} 50 \mathrm{mg}$ 
casein and I $5 \mathrm{mg}$ sodium glutamate/100 $\mathrm{ml}$. This 'inoculum' culture was maintained by daily transfer.

Amino-acid requirements. For the determination of amino-acid requirements the culture was transferred to a defined medium of the composition shown in Table 2, in which abundant growth was obtained. The method of testing for amino-acid requirements was to make, in parallel, two serial subcultures in $(a)$ the complete medium, and $(b)$ the complete medium modified by the omission of each in turn of eighteen amino acids. The cultures were incubated for $20 \mathrm{~h}$ at $37^{\circ}$; a one-drop inoculum was transferred at each subculturing. Growth was assessed by visual observation of the tubes at $20 \mathrm{~h}$, and was scored as: - (no growth),,+++ or +++ .

\section{Table 2. Composition of the defined medium used for determining} amino-acid requirements of Streptococcus zymogenes

$\begin{array}{lrll}\begin{array}{l}\text { Five times strength basal medium } \\ \text { ('Table } \mathrm{r} \text { ) (ml) }\end{array} & 200 & \text { Glycine (mg) } & 200 \\ \text { L-Glutamic acid (mg) } & & \text { L-Cystine (mg) } & 200 \\ \text { L-Leucine (mg) } & 1000 & \text { L-Serine (mg) } & 200 \\ \text { L-Isoleucine (mg) } & 500 & \text { L-Aspartic acid (mg) } & 200 \\ \text { L-Valine (mg) } & 500 & \text { L-Tyrosine (mg) } & 200 \\ \text { L-Lysine (mg) } & 500 & \text { L-Proline (mg) } & 200 \\ \text { L-Arginine (mg) } & 500 & \text { L-Histidine (mg) } & 200 \\ \text { L-Methionine (mg) } & 500 & \text { L-Phenylalanine (mg) } & 200 \\ \text { L-Alanine (mg) } & 500 & \text { L-Threonine (mg) } & 200 \\ & 200 & \text { L-Tryptophan (mg) } & 200\end{array}$

pH adjusted to $7 \cdot 2$.

Water added to $1000 \mathrm{ml}$.

The requirements for eight amino acids were sharply defined and unequivocal: in the absence of arginine, histidine, leucine, isoleucine, methionine, tryptophan, valine or glutamic acid there was no visible growth in the first subculture. In the absence of lysine or serine growth was severely restricted, but continued at + through several transfers. Growth was slightly retarded, to ++ , by the omission of glycine, phenylalanine or cystine. The omission of alanine, proline, threonine, tyrosine or aspartic acid had no apparent effect upon growth.

Cystine 'spared' methionine, in the sense that omission of cystine from the test medium increased the requirement for methionine by about $15 \%$.

\section{Measurement of the 'biological value' of proteins}

Choice of a reference standard. In preliminary tests, samples of Labco vitamin-free casein (The Borden Co, New York) and of dried whole egg were included as standards of comparison. The 'biological value' of the dried whole egg proved unexpectedly low: relative to casein (100) it was rated at 60 . The addition to the dried egg of $5 \%$ L-glutamic acid increased this figure to roo, but larger supplements of glutamic acid, up to $25 \%$, gave no greater improvement. It seemed that, for $S$. zymogenes, the dried egg was severely deficient in glutamic acid. In all subsequent tests, Labco vitamin-free casein was used as the standard of comparison and both it and the various test proteins were supplemented with L-glutamic acid as described below. 
Preparation of proteins for test. The vitamin-free casein and the proteins to be tested were ground in a laboratory mill and sieved through an 80-mesh screen. Samples were then weighed, in amounts containing precisely $100 \mathrm{mg}$ nitrogen, and prepared for test by one of the following procedures:

(a) The samples were stirred for $30 \mathrm{~min}$ at $45^{\circ}$ with $80 \mathrm{ml}$ portions of an aqueous solution of tris-hydroxymethylaminomethane (TRIS) $(0.2 \%, \mathrm{w} / \mathrm{v})$ and Tween 80 (polyoxyethylenesorbitan mono-oleate) $(0.02 \%, \mathrm{w} / \mathrm{v})$. The digests were brought to $\mathrm{pH} 7 \cdot 2$ with $0.2 \mathrm{~N}-\mathrm{H}_{3} \mathrm{PO}_{4}$ and water was added to make the volume to $100 \mathrm{ml}$. Finally, I $\mathrm{ml}$ portions were taken and diluted to $100 \mathrm{ml}$ with a $0.013 \%(\mathrm{w} / \mathrm{v})$ aqueous solution of sodium glutamate.

(b) The samples were transferred to glass-stoppered test tubes, and to each were added $\mathrm{I} 0 \mathrm{ml}$ of an aqueous solution containing, per 1 .: $\mathrm{I} \mathrm{g}$ papain (British Drug Houses Ltd, Poole); $30 \mathrm{mg}$ sodium cyanide; $5 \mathrm{~g}$ sodium citrate, and enough citric acid to bring the $\mathrm{pH}$ value to $7 \cdot 0$. The $\mathrm{pH}$ value of the tube contents was adjusted-if necessary-to $7 \cdot 0$ by the use of narrow-range $\mathrm{pH}$ indicator paper (Johnsons Ltd, Hendon). The tubes were then incubated for $3 \mathrm{~h}$ in a water-bath at $46^{\circ}$, with occasional shaking. After incubation the digests were diluted to $100 \mathrm{ml}$ with water and finally $10 \mathrm{ml}$ portions were taken and diluted to $100 \mathrm{ml}$ with a $0.013 \%(\mathrm{w} / \mathrm{v})$ aqueous solution of sodium glutamate.

Preparation of the test cultures. The assays were set up in wire racks each holding seventy-two $19 \times 150 \mathrm{~mm}$ optically matched Pyrex test tubes. 'Standard' and 'test' preparations were added to paired tubes in amounts of 2, 4, 6 and $8 \mathrm{ml}$. Two $\mathrm{ml}$ of the basal medium (five times single strength, Table $\mathrm{r}$ ) were then added, and water to bring the fluid content of each tube to ro $\mathrm{ml}$. The racks of filled tubes were each covered with a folded towel held firmly in position by an aluminium lid. They were then heated in flowing steam for $5 \mathrm{~min}$, cooled to $37^{\circ}$, inoculated, and put to incubate in a water-bath at $37^{\circ}$.

\section{Measurement of growth responses}

(I) By turbidity measurement. After incubation for $48 \mathrm{~h}$ the racks of tubes were heated in flowing steam for $10 \mathrm{~min}$ and cooled to room temperature. The tubes were stoppered and shaken vigorously and then set aside for $2-3$ min to allow air bubbles to rise and any particulate food residues to settle. The optical densities of the cultures were measured in the tubes at $580 \mathrm{~m} \mu$ with a Lumetron Model 400 A colorimeter (Photovolt Corporation, New York).

(2) By reduction of triphenyltetrazolium chloride. When the test solutions were themselves turbid it was sometimes necessary to assess the growth of the assay organism by an indirect means. A convenient index was the amount of red pigment produced in the test cultures by the enzymic reduction of added triphenyltetrazolium chloride (Anderson \& Williams, 1951). The assay tubes were incubated for $24 \mathrm{~h}$. To each tube were then added $2 \mathrm{ml}$ of a $\mathrm{I} \cdot 5 \%(\mathrm{w} / \mathrm{v})$ solution of $2,3,5$-triphenyltetrazolium chloride in $0.2 \mathrm{M}$-potassium-phosphate buffer of $\mathrm{pH} 7.6$. Incubation was continued for a further $20 \mathrm{~min}$, after which $15 \mathrm{ml}$ acetone were added to each. The tubes were then shaken to extract the red pigment from the cell precipitate, and centrifuged. The 
supernatant liquors were decanted and their colour densities measured at $485 \mathrm{~m} \mu$. The extracts were diluted, if necessary, with $50 \%$ aqueous acetone. To prepare 'blanks', additional tubes were set up at each dose level, and sterilized by autoclaving for $5 \mathrm{~min}$ at $110^{\circ}$ before the addition of the tetrazolium solution. The rate of reduction of the tetrazolium reagent in the test cultures was accelerated by bright light, and it was important to do the test under conditions of subdued lighting.

(3) By measurement of titratable acidity and of lactic-acid production. Titratable acidity developed during $48 \mathrm{~h}$ incubation proved an unreliable index of growth response: with certain 'poor' proteins such as wheat gluten the ratings assigned on the basis of acidity measurements were consistently higher and less precisely reproducible than those computed from turbidity measurements, which were preferred as being a direct measure of the bacterial growth in the culture tubes.

When instead of total acidity the concentrations of lactic acid in the test cultures were measured, the reproducibility of the results and their correlation with results obtained from measurements of optical density were improved. Routine assays of lactic acid were done by the method of Barker \& Summerson (1941). This was, however, a tedious procedure when applied to batches of a hundred or more test cultures, and involved much dispensing of reagents.

Choice of method. With many high-protein foodstuffs growth responses can be accurately assessed photometrically. Even with such insoluble substances as soyabean meal, dried yeast, wheat-gluten meal and fish meals, optical density readings give a reliable indication of bacterial growth if, after the cultures have been shaken and before the readings, time is allowed for insoluble food residues to sink to the bottom of the culture tubes. Some substances, however, for example linseed, sunflower seed and cottonseed meals, give highly coloured, glutinous or turbid extracts; with these, growth responses cannot be assessed photometrically, and the tetrazolium method would be used. This technique needs to be standardized very precisely, and particular care must be taken to ensure that the tetrazolium reagent is thoroughly mixed into the test cultures and that all the cultures are allowed to act on the reagent for the same length of time. Rapidly dispensing syringes of the type of the Manning hand-operated metering pump (A. J. Manning, Alperton, Wembley) should be used for adding the tetrazolium reagent and the acetone.

The tetrazolium method gives results approximately similar to those of the photometric method, but the precision of the measurements is lower and the procedure is somewhat tedious. It should be preferred when the photometric method cannot be employed and when the purpose of the test is to grade proteins of different kinds. For grading samples of similar materials, measurement of total acidity may well give all the information required.

\section{RESULTS AND DISCUSSION}

Predigestion of test proteins. S. zymogenes is itself vigorously proteolytic, but pretreatment of the casein and the test samples with papain improved the assay in several respects. It speeded growth, and improved the linearity and reproducibility of the dose-response curve (Fig. I). Comparison of the curves in Fig. I suggests that after 
predigestion with papain, casein was converted more efficiently-or more quicklyinto bacterial nitrogen. Measurement confirmed that after digestion with papain the proportion of the casein nitrogen incorporated into bacterial cells increased from 64 to $7 \mathrm{x} \%$. With most of the proteins listed in Table 3 , however, papain treatment had little influence on the relative nutritional values obtained.

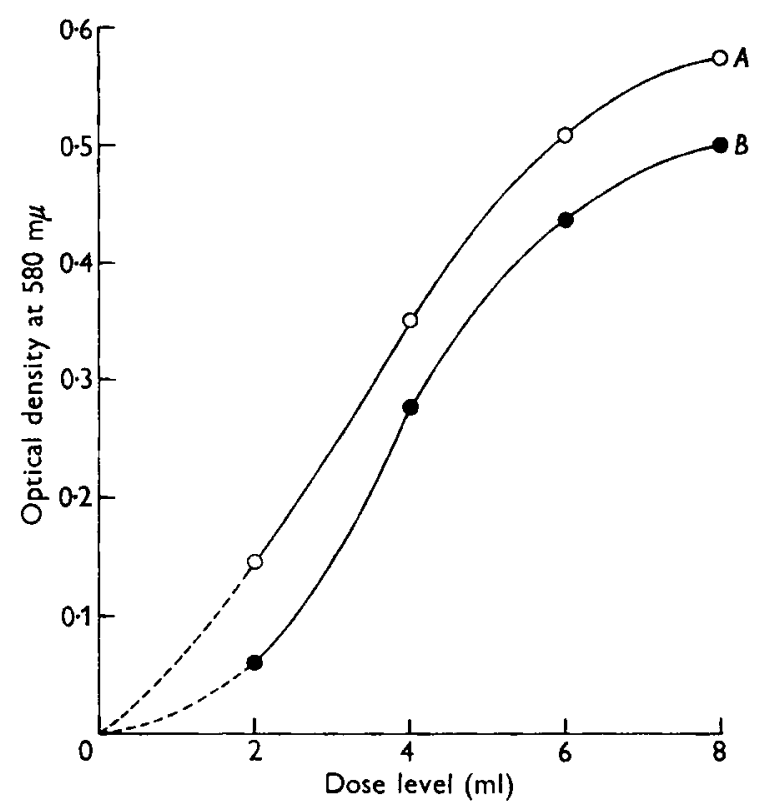

Fig. 1. Growth of $S$. zymogenes during incubation for $48 \mathrm{~h}$ with casein (in solution containing $10 \mathrm{mg}$ casein $\mathrm{N} / 100 \mathrm{ml}$ ); $\bigcirc-0$, treated with papain (p. 488); $\bullet \bullet$, treated with heatinactivated papain.

Survey of protein foodstuffs. A survey was made of a variety of food proteins, among them several (series MM, WM, FM, SM and GN) that had been selected as representative of a wide range of sources and quality, and distributed by the Agricultural Research Council in connexion with its collaborative investigation into the measurement of the quality of protein feeding-stuffs (cf. Anonymous, 1959). The code numbers of samples are those uniformly used by the participants in the collaborative investigation.

Some of the results obtained are given in Table 3 and in Fig. 2. Each of the microbiological assay values represents six or eight observations, being a mean of the values calculated from growth responses in duplicate tubes at three or four dose levels. No assessment has yet been made of the precision of these measurements, but for those substances which, like casein and dried egg, dissolved and formed an almost colourless solution, the errors of measurement were small and similar to those of conventional microbiological assays for vitamins. With certain other substances, for example linseed meal and cottonseed meal, the mechanical difficulties of preparing and dispensing the test extracts and the use of the tetrazolium method for estimating growth responses added appreciably to the errors of measurement. 
The corresponding rat-assay values were kindly provided by my colleague $\mathrm{Dr} \mathrm{K}$. M. Henry, and denote 'net percentage utilization' (Mitchell, 1923-4; Mitchell \& Carman, 1926) and 'net protein ratio' (Bender \& Doell, 1957). It is apparent from Figs. 2 and 3 that the values obtained with these different assay methods were closely correlated.

Table 4 shows values obtained with $S$. zymogenes for several whale-meat meals (series WM), meat meals (series MM) and fish meals (series FM), together with ratings of Bunyan \& Price (1960) for these same materials, expressed in terms of net percentage utilization, net protein ratio, 'available' lysine, and $S$. faecalis values. It is apparent from Fig. $3 A-D$ that the values obtained with $S$. zymogenes were closely correlated with each of these four sets of values.

For their tests with $S$. faecalis, Bunyan \& Price (1960) followed the procedure outlined by Halevy \& Grossowicz (1953) but prepared the proteins for test by the

\section{Table 3. Relative values of different proteins for Streptococcus} zymogenes and for the rat

\begin{tabular}{|c|c|c|c|c|c|}
\hline \multirow[b]{2}{*}{ Test protein } & \multicolumn{3}{|c|}{$\begin{array}{l}\text { Relative nutritional values for } \\
\qquad \text { S. zymogenes }\end{array}$} & \multicolumn{2}{|c|}{$\begin{array}{l}\text { Biological value for } \\
\text { the rat* }\end{array}$} \\
\hline & At & $\mathrm{B} \ddagger$ & $C \S$ & N.P.v. & N.P.R. \\
\hline Labco casein|| & 100 & 100 & 100 & - & - \\
\hline Genatosan casein 9 & 94 & 99 & 104 & 84 & 3.92 \\
\hline Dried whole egg & 90 & 94 & 94 & 95 & $4 \cdot 66$ \\
\hline Dried skim milk: SM8 & 99 & 99 & 99 & 78 & 3.77 \\
\hline SMI9 & IO2 & 106 & 109 & 89 & $4 \cdot I I$ \\
\hline Dried buttermilk: SM29 & ro4 & 107 & - & $8 \mathbf{3}$ & 4.21 \\
\hline Soya-bean meal: unsupplemented & 67 & $71 \cdot 5$ & 63 & 70 & $3 \cdot 37$ \\
\hline$+1 \%$ methionine & 85 & 90 & - & 82 & $4 \cdot 03$ \\
\hline Drackett soya protein*** & 62 & 56 & 58 & 63 & $2 \cdot 71$ \\
\hline Dried food yeast & 68 & 80 & - & 69 & $3 \cdot 10$ \\
\hline Fish meal: FM 17 & $3^{8}$ & 52 & - & 54 & $2 \cdot 85$ \\
\hline FM6 & 70 & 74 & 76 & 89 & 4.02 \\
\hline Meat meal: $\mathrm{MM}_{3}$ & 39 & 32 & - & - & - \\
\hline MM Io & 42 & 39 & - & 40 & 0.98 \\
\hline MM I6 & 32 & 26 & - & - & - \\
\hline MM I 8 & 52 & 50 & - & 54 & $2 \cdot 40$ \\
\hline $\mathrm{MM}_{20}$ & $3 \mathrm{I}$ & 19 & - & 43 & $1 \cdot 70$ \\
\hline Wheat gluten & 54 & 55 & 56 & 54 & $2 \cdot 79$ \\
\hline Maize gluten & 73 & 68 & - & - & - \\
\hline Groundnut meal: GN 12 & 53 & 54 & - & 58 & $2 \cdot 72$ \\
\hline
\end{tabular}

Net protein utilization (N.P.U.) $=\frac{\text { biological value } \times \text { true digestibility }}{100}$. Values were obtained by the balance-sheet method of Mitchell, with $8 \%$ protein in the test diets (Mitchell, 1923-4; Mitchell \& Carman, 1926).

Net protein ratio (N.P.R.) $=$ (gain in weight of test group + loss of weight of non-protein group) $\div$ protein intake (Bender \& Doell, r 957 ).

For meanings of reference code numbers, see p. 490.

* Kindly provided by Dr K. M. Henry.

+ 'Test proteins 'dissolved' in TRIS buffer (see p. 488). Growth responses measured turbidimetrically.

I Test proteins predigested with papain (see p. 488). Growth responses measured turbidimetrically.

$\S$ Test proteins predigested with papain. Growth responses measured enzymically, by reduction of triphenyltetrazolium chloride (see p. 488).

II Vitamin-free, The Borden Co, New York.

I Genatosan Ltd, Loughborough.

** Isolated soya proteins: The Drackett Co., Cincinnati. 
method of Bondi \& Birk (1955), in which overnight digestion with pepsin is followed by overnight digestion with pancreatin. Graded amounts of these enzymic digests were added to the culture tubes to serve as the sole source of essential amino acids for the test micro-organisms. Quantitative assessment of the results was difficult because the dose-response curves varied considerably in curvature from sample to sample, and attempts to compare growth responses at fixed levels of protein were dependent upon the level chosen. Despite this complication, their results correlate very closely $(r=0.93)$ with those obtained with $S$. zymogenes.

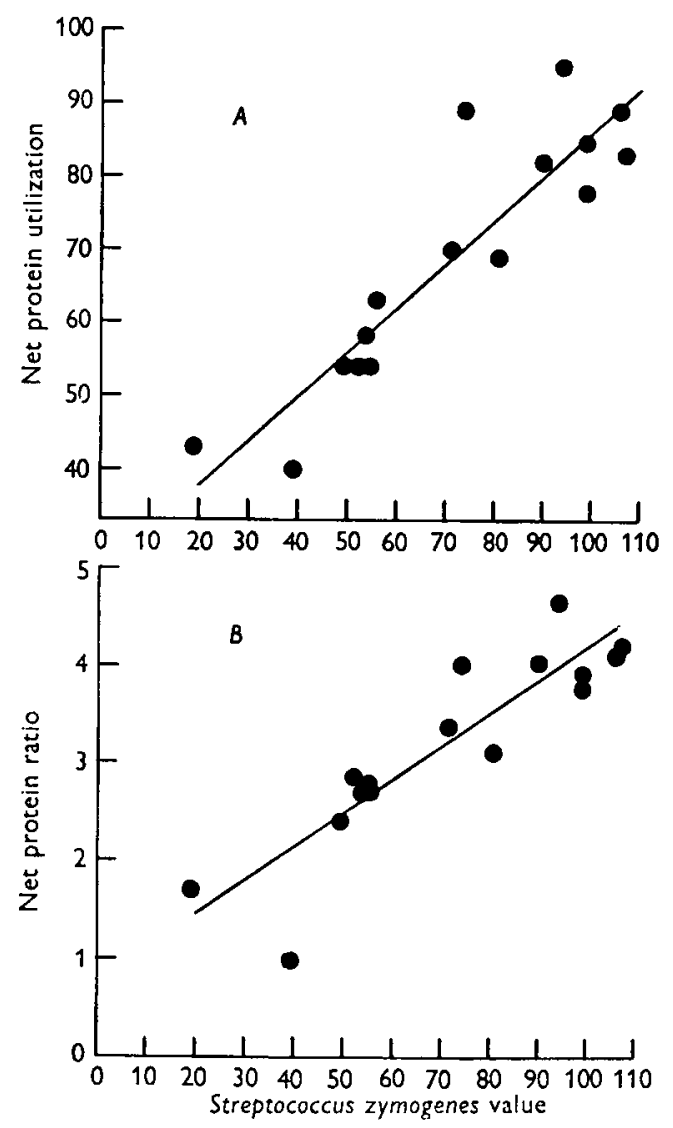

Fig. 2. Correlation between $S$. zymogenes rating for a variety of food proteins, and $(A)$ net protein utilization (rat), $(B)$ net protein ratio (rat).

$(A)$ N.P.U.* $=26.4+0.60 S$. zymogenes rating; standard error of regression coefficient $=$ $\pm 0.08 ; r=0.90$ (I4 d.f.), $P<0.00$ I. $(B)$ N.P.R.* $=0.79+0.034 S$. zymogenes rating; standard error of regression coefficient $= \pm 0.005 ; r=0.89$ (14 d.f.), $P<0.001$.

* Values (unpublished) of Dr K. M. Henry.

$S$. faecalis and $S$. zymogenes are closely related species and they have much the same requirements for exogenous amino acids, except that in $S$. faecalis the need for lysine is absolute. This would seem to recommend the organism for evaluating proteins such as maize gluten which are primarily deficient in lysine. Certainly the rating of 68 (casein = 100; Table 3 ) obtained with $S$. zymogenes for a sample of maize-gluten meal 
seems unduly high, and $S$. faecalis might have returned a markedly lower value. On the other hand, the addition of lysine ( $1 \%$ ) increased this value of 68 to 82 ; similarly, the addition of lysine caused a marked increase in the rating of wheat gluten and of overheated roller-dried milk. It appears that under the conditions of the microbiological test, in which nitrogen is made limiting, the growth of $S$. zymogenes may be sharply restricted by a deficiency of lysine. And if $S$. zymogenes may place too little emphasis on lysine deficiency, it is possible that, compared with the rat, $S$. faecalis shows an exaggerated requirement for lysine. Halevy \& Grossowicz (1953) found that, for $S$. faecalis, casein and egg albumin were severely deficient in lysine, whereas biological tests with rats (Frost, I950) showed methionine to be the limiting amino

Table 4. Meat and fish meals: ratings by different tests of protein quality

\begin{tabular}{|c|c|c|c|c|c|}
\hline $\begin{array}{c}\text { No. of } \\
\text { meal }\end{array}$ & $\begin{array}{c}\text { Streptococcus } \\
\text { zymogenes } \\
\text { test* }\end{array}$ & $\begin{array}{c}\text { Streptococcus } \\
\text { faecalis } \\
\text { test } * \dagger\end{array}$ & $\begin{array}{c}\text { Available' } \\
\text { lysine } \\
\text { (g/16g N)† }\end{array}$ & $\begin{array}{c}\text { Net } \\
\text { protein } \\
\text { utilization }\end{array}$ & $\begin{array}{l}\text { Net } \\
\text { proteir } \\
\text { ratiot }\end{array}$ \\
\hline WM I & 55 & 86 & $4 \cdot 5$ & 25 & $I \cdot 0$ \\
\hline $\mathrm{WM}_{2}$ & $5^{8}$ & IOI & 6.3 & 36 & $2 \cdot 0$ \\
\hline $\mathrm{WM}_{3}$ & 62 & 105 & 7.0 & 44 & $2 \cdot 5$ \\
\hline$W_{4}$ & 73 & 113 & $8 \cdot 1$ & 57 & $3 \cdot 2$ \\
\hline $\mathrm{WM}_{5}$ & 55 & 102 & $7 \cdot 1$ & 37 & $2 \cdot 0$ \\
\hline WM 6 & 70 & 116 & 6.4 & 52 & $2 \cdot 9$ \\
\hline $\mathrm{WM}_{7}$ & 26 & 58 & $3 \cdot 3$ & 17 & 0.6 \\
\hline WM9 & 68 & 127 & 7.0 & 61 & $3 \cdot 5$ \\
\hline WM ro & 52 & 95 & 5.4 & 35 & $r \cdot 7$ \\
\hline WM I I & 66 & 106 & $6 \cdot 6$ & 41 & $2 \cdot 8$ \\
\hline WM 12 & 63 & 94 & $5 \cdot I$ & 31 & $I \cdot 6$ \\
\hline WM $\mathbf{I}_{3}$ & 83 & 127 & $7 \cdot 3$ & 62 & $3 \cdot 3$ \\
\hline $\mathbf{M M}_{3}$ & 32 & 36 & $3 \cdot 6$ & 9 & 0.4 \\
\hline MM 10 & 39 & 40 & 3.7 & 14 & 0.8 \\
\hline MM r6 & 26 & 36 & $2 \cdot 6$ & 26 & $I \cdot 5$ \\
\hline MM I 8 & 50 & 64 & 4.9 & $3 I$ & $I-8$ \\
\hline $\mathrm{MM}_{20}$ & 19 & 36 & $1 \cdot 2$ & 32 & $X \cdot I$ \\
\hline FM6 & 74 & - & $6 \cdot 4$ & 59 & $3 \cdot 6$ \\
\hline FM 17 & $5^{2}$ & - & $4 \cdot 3$ & 22 & $I \cdot 4$ \\
\hline
\end{tabular}

For meaning of reference code numbers see p. 490 .

* Relative to casein $=100$.

+ Values of Bunyan \& Price (1960).

acid in casein, and isoleucine the limiting amino acid in egg albumin. Rogers, McLaughlan \& Chapman (1959) also reported that, compared with the rat, $S$. faecalis has a high requirement for lysine.

The requirement of $S$. zymogenes for lysine is not absolute, and the close correlation $(r=0.91$; Fig. $3 D)$ between 'available' lysine values and $S$. zymogenes ratings was therefore of special interest. Tests showed, however, that addition of L-lysine ( $2 \%)$ to whale-meat meals $\mathrm{WM}_{1}, \mathrm{WM}_{5}, \mathrm{WM}_{7}, \mathrm{WM}_{\text {ro }}$ and $\mathrm{WM}_{3} 3$ caused little or no improvement in their value for S. zymogenes. Supplements of methionine ( $1 \%$ ), and of L-methionine together with L-lysine, were also ineffective, and L-tryptophan $(0.5 \%)$ lowered the values of three of the meals-WM $-W_{1}, W_{5}$ and $W_{7}$. In further

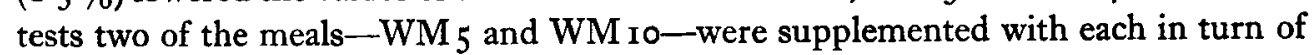


ten amino acids, namely L-arginine ( $1 \%$ ), L-histidine $(0.5 \%)$, L-lysine ( $1 \%$, Lphenylalanine (1 \%), L-tryptophan $(0.5 \%)$, L-methionine $(0.5 \%)$, L-threonine $(1 \%)$, L-leucine ( $\mathrm{I} \%$ ), L-isoleucine ( $\mathrm{I} \%$ ) or $\mathrm{L}$-valine ( $\mathrm{r} \%$ ). It was found that no one of these 'essential' amino acids improved the value of either of the meals.

It appears that none of the samples was necessarily deficient primarily in lysine despite the close correlation between 'available' lysine and $S$. zymogenes values. It is possible that the differences in biological value reflect differences in the availability,
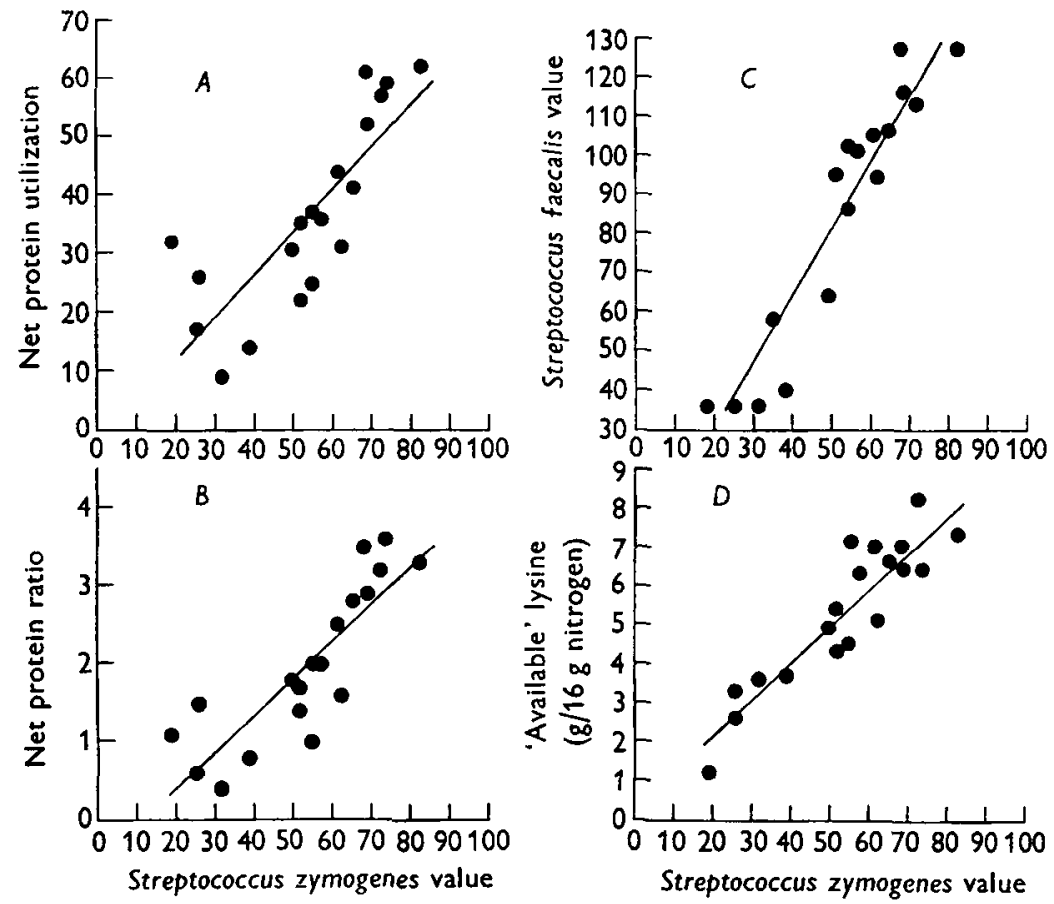

Fig. 3. Correlation between $S$. zymogenes rating for whale-meat meals, fish meals and meat meals, and $(A)$ net protein utilization (rat), $(B)$ net protein ratio (rat), $(C) S$. faecalis rating, $(D)$ 'available' lysine value.

(A) N.P.U.* $=-2 \cdot 28+0.72 S$. zymogenes rating; standard error of regression coefficient $=$ $\pm 0.13 ; r=0.81$ (17 d.f.), $P<0.001$. (B) N.P.R. $*=-0.56+0.047 S$. zymogenes rating; standard error of regression coefficient $= \pm 0.007 ; r=0.85$ (17 d.f.), $P<0.001$. (C) $S$. faecalis rating* $=-2 \cdot 94+\mathrm{I} \cdot 67 \quad S$, zymogenes rating; standard error of regression coefficient $= \pm 0.16 ; r=0.93$ (I5 d.f.), $P<0.001$. (D) A.L.v. $*=0.30+0.093$ S. zymogenes rating; standard error of regression coefficient $= \pm 0.010 ; r=0.91$ (17 d.f.), $P<0.001$.

* Values from Bunyan \& Price (1960).

rather than in the amounts, of several or all of the amino acids contained in them. Some indication that this may be so is given by the following experiment. Four of the samples-WM $5, \mathrm{WM}_{7}, \mathrm{WM}_{10}$ and $\mathrm{WM}_{13}$-were prepared for test by autoclaving with $4 \mathrm{~N}-\mathrm{HCl}$ for $4 \mathrm{~h}$ at $12 \mathrm{I}^{\circ}$. The hydrolysates were supplemented with tryptophan (100 $\mathrm{mg} / \mathrm{g} \mathrm{N}$ ) and cysteine ( $200 \mathrm{mg} / \mathrm{g} \mathrm{N}$ ), which were presumed to have been largely destroyed during the acid hydrolysis. The values obtained with these preparations, compared with those obtained by preparing the samples for test in the usual manner 
(p. 488), are shown in Table 5. Sample $\mathrm{WM}_{13}$ was rated highly in a variety of tests (Table 4). Its value for $S$. zymogenes was reduced by $30 \%$, from 77 to 53 , by hydrolysis with acid even after the restoration of tryptophan and cysteine. In contrast, the value of $\mathrm{WM}_{7}$, the poorest of the samples (Table 4 ), was increased by $125 \%$, from I8 to $4 \mathrm{I}$.

Effects of heating on the nutritional value of a chick diet

My colleague Dr M. E. Coates found that autoclaving a good practical chick diet, containing $10 \%$ dried skim milk, greatly impaired its nutritional value for chicks. Duplicate groups of twenty chicks were reared to 3 weeks of age on the unheated diet

Table 5. Influence of acid hydrolysis and subsequent supplementation with amino acids on the nutritional value of whale-meat meals

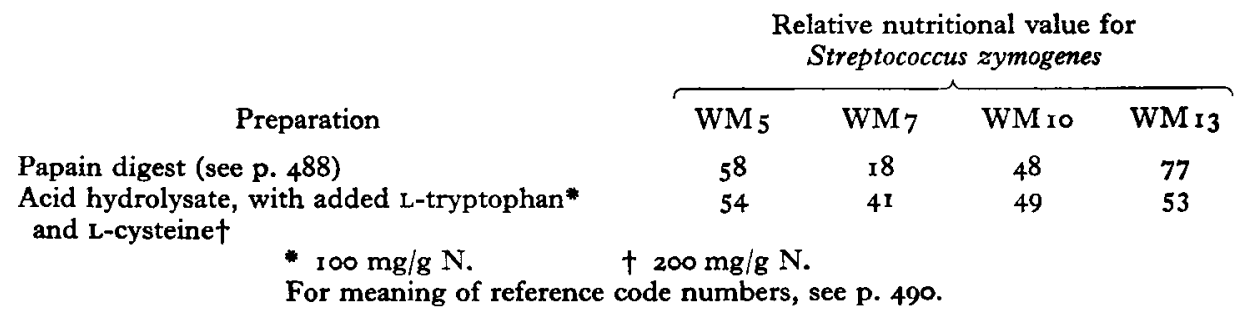

Table 6. Effects of heating and of subsequent supplementation with amino acids on the nutritional value of a chick diet

$\begin{array}{lc}\text { Supplement } & \begin{array}{c}\text { Relative nutritional } \\ \text { value } \\ \text { Unheated } \\ \text { (casein }=\text { 100) }\end{array} \\ \text { None } & \\ \text { Autoclaved 30 min at I } 15^{\circ} & 70 \\ \text { None } & 27 \\ \text { Any one 'essential' amino acid } & \text { c. } 27 \\ \text { Ten 'essential' amino acids } & 69 \\ \text { Ten 'essential' amino acids excepting: } & \\ \text { Arginine } & 33 \\ \text { Histidine } & 39 \\ \text { Isoleucine } & 24 \\ \text { Leucine } & 35 \\ \text { Lysine } & 4 \mathrm{I} \\ \text { Methionine } & 36 \\ \text { Phenlalanine } & 55 \\ \text { Threonine } & 34 \\ \text { Tryptophan } & 44 \\ \text { Valine } & 32\end{array}$

or on the diet that had been autoclaved for $3^{\circ} \mathrm{min}$ at $115^{\circ}$ and then supplemented with all the vitamins. The mean weights of the groups of birds fed on the unheated diet were 189 and $177 \mathrm{~g}$; those fed on the heated diet weighed 85 and $64 \mathrm{~g}$.

Tests with $S$. zymogenes (Table 6) showed that heating had severely reduced the 'biological value' of the dietary protein. Supplementation of the heated diet with 
each in turn of the ten 'essential' amino acids at $10 \mathrm{mg} / 100 \mathrm{mg}$ nitrogen, gave no improvement, but when all ten amino acids were added together the value of the diet was increased and equalled that of the unheated diet. The similarity of these latter values is probably fortuitous. It is more significant that the omission from the complete supplement of any one of ten 'essential' amino acids caused a marked fall in the nutritional value of the autoclaved diet. It would seem that with these chick diets, as with the whale-meat meals, the differences in nutritional value may reflect differences in the availability of several or all of the amino acids contained in them.

Supplementation of proteins with amino acids. Compared with the protein of dried whole egg, wheat gluten is low in lysine and methionine. Making good the deficiency of lysine by addition of $4 \mathrm{~g}$ L-lysine/ $16 \mathrm{~g}$ nitrogen increased the relative nutritive value for $S$. zymogenes $(\mathrm{egg}=100$ ) only from 57 to 61 . The corresponding addition of $2 \mathrm{~g}$ $\mathrm{L}$-methionine gave a value of $8 \mathrm{I}$. The further addition of L-lysine increased this latter value to 99 . Similarly, the addition of methionine ( $\mathrm{I} \%$ ) increased the relative nutritive value (casein $=100$ ) of a soya-bean meal from $71 \cdot 5$ to 90 , and of roller-dried skim milk from 93 to rog.

In conclusion it seems that, at least for the limited range of food proteins examined, results obtained with $S$. zymogenes would support predictions of biological values for the rat, and would indicate reliably any diversity of quality within groups of similar materials. Further comparative tests will be necessary to establish for each class of foodstuff that the microbiological method gives ratings similar to those obtained in biological tests.

S. zymogenes is potentially useful for measuring certain individual amino acidsmethionine, tryptophan, arginine, histidine, leucine, isoleucine, valine and glutamic acid-both free and in intact proteins. Work on the estimation of 'total' and 'available' methionine, leucine and tryptophan in food proteins is now in progress.

\section{S U M M A R Y}

I. A strain of Streptococcus zymogenes, NCDO 592, needed broadly the same amino acids as the growing rat. It was powerfully proteolytic and grew quickly with an adequate intact protein as the main source of nitrogen.

2. A method of assay was developed in which $S$. zymogenes, NCDO $59^{2}$, was used to provide an estimation of protein quality. Values obtained for a variety of food proteins were found to correlate closely with those obtained in biological tests with rats.

3. Values obtained for several meat meals were closely correlated with their content of 'available' lysine. However, none of the meals was necessarily deficient primarily in lysine, at least for $S$. zymogenes. The differences in nutritional value seemed to reflect differences in the availability, rather than in the total amounts, of several or all of the amino acids.

I am indebted to Dr K. M. Henry for the biological-assay values listed in Table 3 ; to Miss Zena D. Hosking for the statistical analyses that accompany Figs. 2-7; to Dr S. K. Kon and Dr G. D. Rosen for helpful advice; and to Mr J. P. Fordham for technical assistance. 


\section{REFERENCES}

Anderson, M. E. \& Williams, H. H. (195I). F. Nutr. 44, 335.

Anonymous (1959). Nature, Lond., 183, 1303.

Barker, S. B. \& Summerson, W. M. (194I). F. biol. Chem. 138, 535.

Bender, A. E. \& Doell, B. H. (1957). Brit. F. Nutr. II, 140.

Bondi, A. \& Birk, Y. (1955). Ұ. Sci. Fd Agric. 6, 543.

Bunyan, J. \& Price, S. A. (1960). F. Sci. Fd Agric. I1, 25.

Evans, R. \& Butts, H. A. (1948). F. biol. Chem. 175, I 5.

Ford, J. E., Perry, K. D. \& Briggs, C. A. E. (1958). F. gen. Microbiol. 18, 273.

Frost, D. V. (1950). In Protein and Amino Acid Requirements of Mammals, p. 33. (A. A. Albanese, editor.) New York: Academic Press Inc.

Halevy, S. \& Grossowicz, N. (1953). Proc. Soc. exp. Biol., N.Y., 82, 567.

Horn, M. J., Blum, A. E., Womack, M. \& Gersdorf, C. E. F. (1952). F. Nutr. 48, 231.

Horn, M. J., Blum, A. E. \& Womack, M. (1954). I. Nutr. 52, 375.

Mitchell, H. H. (1923-4), F. biol. Chem. 58, 873 .

Mitchell, H. H. \& Carman, G. G. (1926). F. biol. Chem. 68, 183.

Rogers, C. G., McLaughlan, J. M. \& Chapman, D. G. (1959). Canad. Y. Biochem. Physiol. 37 , 135 I. Rose, W. C. (1938). Physiol. Rev. 18, 109.

Rosen, G. D. (1960). In Proceedings of the International Symposium on Microchemistry held at Birmingham University, 20-27 August, 1958, p. 212. London: Pergamon Press.

Rosen, G. D. \& Fernell, W. R. (1956). Brit. F. Nutr. ro, 156. 